\title{
PENGELOLAAN KELAS SEBAGAI UPAYA MENCIPTAKAN PEMBELAJARAN BAHASA ARAB YANG EFEKTIF
}

\section{Siti Baengatun, Rochanah Rochanah \\ IAIN Kudus}

bengatunsiti9@gmail.com

hana@stainkudus.ac.id

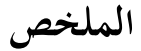

إدارة الصف هي واحدة من المهارات التي يجب أن يمتلكها المعلم. لذلك ، يتعين على كل معلم أن يكون لديه مهارات إبداعية في تهيئة جو مفضّل في الفصل في عملية التعلم. الغرض من إدارة فصول تعلم اللغة العربية هو خلق جو تعليمي فعال باللغة العربية. هذا البحث هو بحث المكتبة ، أي البحث الذي أجري مع الأدب (الأدب). تقنيات جمع البيانات من خلال تحديد الخطابات من الكتب والمقالات والبحلات. المشكلة التي أثنارها الباحثون في هذه الدراسة هي: كيف يتم إدارة الفصل في خلق تعلم فعال للغة العربية؟ تشير نتائج الدراسة إلى أنه أولاً ، يجب الانتباه إلى مكونات مهارات إدارة الفصل ، وهي: أ. المهارات المتعلقة بإنشاء وصيانة الظروف التعليمية (الوقائية) المثلى ، بما في ذلك الاستجابة ومشاركة الاهتمام. ب. المهارات



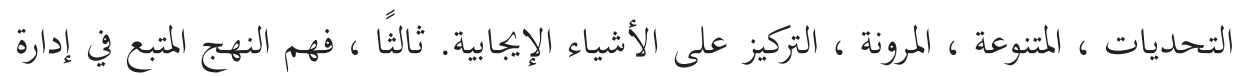
الفصل ، بما في ذلك: مقاربات القوة ، مناهج التدريس ، مناهج العمل الجماعي ، النهج التعددية أو الاختيارية . الكلمات المفتاحية: إدارة الصف ؛ تعلم اللغة العربية, فعال
\end{abstract}




\begin{abstract}
Abstrak
Pengelolaan kelas merupakan salah satu keterampilan yang harus dimiliki seorang pendidik. Karenanya, setiap pendidik dituntut untuk memiliki keterampilan yang kreatif dalam menciptakan suasana kelas yang kondusif dalam proses pembelajaran. Tujuan dari pengelolaan kelas pembelajaran bahasa Arab adalah menciptakan suasana pembelajaran bahasa Arab yang efektif. Penelitian ini adalah penelitian kepustakaan (library research) yaitu penelitian yang dilaksanakan dengan literatur (kepustakaan). Teknik pengumpulan data melalui identifikasi wacana dari buku-buku, artikel, dan jurnal. Permasalahan yang peneliti angkat dalam penelitian ini yakni; Bagaimana pengelolaan kelas dalam menciptakan pembelajaran bahasa Arab yang efektif?. Hasil penelitian menunjukkan bahwa Pertama, memperhatikan komponen-komponen keterampilan mengelola kelas, yakni: a. Keterampilan yang berhubungan dengan penciptaan dan pemeliharaan kondisi belajar yang optimal (bersifat preventif), meliputi sikap tanggap dan membagi perhatian. b. Keterampilan yang berhubungan dengan pengembangan kondisi yang optimal. Kedua, mengetahui prinsip-prinsip pengelolaan kelas, yakni: hangat dan antusias, tantangan, bervariasi, keluwesan, penekanan pada hal-hal yang positif. Ketiga, memahami pendekatan dalam pegelolaan kelas, meliputi: pendekatan kekuasaan, pendekatan pengajaran, pendekatan kerja kelompok, pendekatan elektis atau pluralistic.
\end{abstract}

Kata kunci: Pengelolaan kelas; pembelajaran bahasa Arab; efektif

\title{
A. PENDAhuluan
}

Pembelajaran bahasa Arab adalah proses interaksi dan penyampaian ilmu oleh pendidik bahasa Arab kepada peserta didik dengan tujuan agar peserta didik memahami dan menguasai bahasa Arab serta dapat mengembangkannya. Dalam kegiatan pembelajaran khususnya pembelajaran bahasa Arab, peran pendidik sangatlah penting terhadap pencapaian tujuan pembelajaran yang dilaksanakan. Pendidik merupakan central utama yang menjadi panutan peserta didik dalam hal pembelajaran. Selain mengajar dan mendidik, tugas pendidik juga berupaya mengelola situasi kelas dengan cara menciptakan kelas supaya menjadi tempat yang nyaman dan menyenangkan bagi peserta didik. Jika suasana kelas telah tercipta menjadi suasana yang nyaman dan menyenangkan, maka besar kemungkinan proses pembelajaran dapat berlangsung secara optimal, materi 
dapat diterima dengan baik, dan peserta didik dapat dengan mudah mengikuti proses belajar. Pengelolaan kelas yang dilakukan tersebut tidak hanya sekedar menyulap suasana kelas menjadi nyaman, melainkan bagaimana pendidik dapat mengatur dan mengorganisasi semua komponen pembelajaran yang meliputi tujuan pembelajaran bahasa Arab, bahan pelajaran bahasa Arab, kegiatan pembelajaran, metode yang digunakan, serta evaluasi yang nantinya menjadi tolak ukur pencapaian hasil belajar peserta didik selama mengikuti pembelajaran.

Adanya pengelolaan kelas ini bertujuan untuk menciptakan dan mempertahankan suasana dan kondisi kelas yang menyenangkan, serta peserta didik dapat lebih mudah terampil dalam berbahasa yang meliputi keterampilan istima', keterampilan qiro'ah, keterampilan kalam, dan keterampilan menulis sehingga pengelolaan kelas tersebut bertujuan salah satunya agar proses pembelajaran dapat berlangsung secara efektif dan efisisen. Efektif yang dimaksud tercapainya tujuan sesuai dengan perencanaan yang dibuat. Sedangkan efisien berarti pencapaian tujuan pembelajaran tidak membutuhkan waktu yang lama. Karena bagaimana suatu materi bisa diterima dengan baik oleh peserta didik ditentukan bagaimana pendidik mengelola kelas yang dihadapinya tersebut. Karena tidak dipungkiri, selama kegiatan pembelajaran berlangsung akan ditemukan masalah yang menghambat jalannya proses pembelajaran. Sehingga dengan adanya pengelolaan kelas tersebut, dapat membantu pendidik dalam melancarkan kepada tersampainya materi dan tujuan pembelajaran.

Dengan demikian dapat dipahami bahwa kegiatan pembelajaran membutuhkan adanya proses perencanaan yang berkaitan dengan segala komponen pembelajaran, yaitu berupa pengelolaan kelas. Keberhasilan dan kegagalan pendidik mencapai tujuan pembelajaran sangat ditentukan dengan kemampuan pendidik dalam mengelola kelas. Dan setiap pendidik dituntut memiliki keterampilan yang baik dalam mengelola kelas sehingga dapat tercipta suasana kondusif guna menunjang proses pembelajaran yang optimal. Berdasarkan paparan yang telah peneliti uraikan diatas, peneliti tertatik untuk 
melakukan penelitian dengan judul "Pengelolaan Kelas Sebagai Upaya Menciptakan Pembelajaran Bahasa Arab Yang Efektif”

Adapun permasalahan yang hendak peneliti kaji dalam penelitian ini adalah: Bagaimana pengelolaan kelas dalam menciptakan pembelajaran yang efektif ?. Penelitian dengan judul "Pengelolaan Kelas Sebagai Upaya Menciptakan Pembelajaran Bahasa Arab Yang Efektif" merupakan penelitian kepustakaan (library research) yaitu penelitian yang dilaksanakan dengan literatur (kepustakaan), baik berupa buku, catatan, maupun laporan hasil penelitian dari penelitian terdahulu. Teknik pengumpulan data melalui identifikasi wacana dari buku-buku, artikel, majalah, jurnal, web internet ataupun informasi lainnya yang berhubungan dengan judul penulisan untukmencari hal-hal atau variabel yangberupa catatan, transkip, buku, surat kabar, majalah dan sebainya yang berhubungan dengan penelitian yang sedang dikaji. Langkah langkah yang dilakukan adalah: 1) Mengumpulkan data-data yang ada baik melalui buku-buku, dokumen, majalah, web (internet). 2) menganalisis data yang telah diperoleh sehingga peneliti bisa menyimpulkan tentang masalah yang dikaji.

\section{B. Pembahasan}

\section{Pendidik}

Menurut Undang-Undang Republik Indonesia No. 14 Tahun 2005 tentang Pendidik dan Dosen, pendidik adalah pendidik professional dengan tugas utama mendidik, mengajar, membimbing, mengarahkan, melatih, menilai dan mengevaluasi peserta didik pada pendidikan usia dini, pendidikan dasar, dan pendidikan menengah. (Supardi, 2004: 52)

Dalam UU No.20 Tahun 2003, Pasal 39 (2), dijelaskan bahwa pendidik adalah tenaga profesional yang bertugas merencanakan dan melaksankan proses pembelajaran, melakukan pembimbingan dan pelatihan, serta melakukan penelitian dan mengabdi kepada masyarakat, terutama bagi pendidik pada perpendidikan tinggi. Demikian juga Sardiman menuturkan bahwa pendidik atau pendidik adalah salah satu komponen manusiawi dalam proses belajar-mengajar, 
yang ikut berperan dalam usaha pembentukan sumber daya manusia yang potensial di bidang pembangunan (Sardiman, 2005: 125).

Dalam kegiatan pembelajaran, peran seorang pendidik sangat menentukan berhasil atau tidaknya suatu pembelajaran. Oleh karenanya pendidik perlu memanajemen dan mengelola kelas supaya peserta didik tetap dapat merasa nyaman dan materi dapat diterima dengan baik oleh peserta didik. Dalam kaitannya dengan pengelolaan kelas, seorang pendidik dituntut mengoptimalkan suasana pembelajaran yang ideal.

Kedudukan pendidik dalam kegiatan pembelajaran sangat strategis dan menentukan. Strategis karena pendidik akan menentukan kedalaman dan keluasan materi pelajaran, sedangkan bersifat menentukan karena pendidik yang membuat peserta didik mengerti bahan pelajaran yang akan disajikan kepada mereka. Salah satu faktor yang mempengaruhi tugas pendidik ialah kinerjanya di dalam merencanakan atau merancang, melaksanakan dan mengevaluasi proses pembelajaran. Pendidik mempunyai tugas untuk mendorong, membimbing, dan memberi fasilitas belajar bagi peserta didik untuk mencapai tujuan (Kompri, 2016: 14).

Dalam perannya sebagai pengelola kelas (learning manager), pendidik hendaknya mampu mengelola kelas sebagai lingkungan belajar serta merupakan aspek dari lingkungan sekolah yang perlu diorganisasi. Lingkungan ini diatur dan diawasi agar kegiatan-kegiatan belajar terarah kepada tujuan-tujuan pendidikan. Lingkungan yang baik ialah lingkungan yang menantang dan merangsang peserta didik untuk belajar, memberikan rasa aman dan kepuasan dalam mencapai tujuan.

Sebagai manager, pendidik bertanggung jawab memelihara lingkungan fisik kelasnya agar senantiasa menyenangkan untuk belajar dan mengarahkan atau membimbing proses-proses intelektual dan sosial di dalam kelasnya. Dengan demikian, pendidik tidak hanya memungkinkan peserta didik belajar, tetapi juga mengembangkan kebiasaan bekerja dan belajar secara efektif di kalangan peserta didik. Sebagai manager, pendidik hendaknya mampu 
memimpin kegitan belajar yang efektif serta efisien dengan hasil optimal. Sebagai manager lingkungan belajar, pendidik hendaknya mampu mempergunakan pengetahuan tentang teori pembelajaran, dan teori perkembangan sehingga kemungkinan untuk menciptakan situasi pembelajaran yang menimbulkan kegiatan belajar pada peserta didik akan mudah dilaksanakan dan sekaligus memudahkan pencapaian tujuan yang diharapkan (Usman, 2009: $10)$.

Sebagaimana dijelaskan oleh Moh. Uzer bahwa keterampilan pendidik dalam mengelola kelas meliputi empat komponen, yaitu: (Wiyani, 2013: 88).

a. Keterampilan mengadakan pendekatan secara pribadi

b. Keterampilan mengorganisasi

c. Keterampilan membimbing

d. Keterampilan melaksanakan dan merencanakan kegiatan belajar-mengajar.

Dari beberapa uraian diatas, telah dijelaskan bahwa salah satu keterampilan seorang pendidik adalah melibatkan peserta didik dalam mengorganisasikan dan mrencanakan kegiatan pembelajaran. Artinya, dalam usaha mengelola kelas supaya tercipta kelas yang kondusif sehingga peserta didik merasa nyaman ketika proses belajar berlangsung, pendidik hendaknya berfikir sekreatif mungkin dalam menyesuaikan kegiatan pembelajaran yang disesuaikan dengan kemauan peserta didik dalam program perencanaan kegiatan pembelajaran. Perencanaan tersebut dapat berupa bagaimana metode yang digunakan dalam kegiatan pembelajaran yang akan dilaksanakan, bagaimana standar penilaian yang diterapkan, bagaimana mengatur suasana kelas agar dapat menjadi lingkungan belajar yang menyenangkan, dan mengenai perencanaan pembelajaran yang akan dilaksanakan.

Dengan dimilikinya keterampilan-keterampilan tersebut, diharapkan pendidik dapat mengelola kelas dengan baik dalam kondisi apapun, sehingga peserta didik dapat menunjukkan ketekunan semangat dalam belajar serta berperan aktif dalam proses pembelajaran terutama dalam pembelajaran bahasa Arab. 
Untuk dapat menciptakan suasana kelas yang menggairahkan diperlukan peran pendidik, peran peserta didik, dan kaidah dalam membangun kelas yang menggairahkan (Munir, 2017: 84)

\section{Peran Pendidik dalam Menciptakan Kelas yang Menggairahkan}

Dalam proses pembelajaran seorang pendidik merupakan pusat atau center kelas. Semua yang diucapkan dan dilakukan pendidik itu nantinya yang akan diterima oleh murid. Berkaitan dengan pembelajaran, seorang pendidik bisa saja menyuguhkan model kelas yang nyaman dan kondusif. Ataupun sebaliknya, yang hanya datang, duduk, kemudian pulang. Semua tergantung pada tingkat keterampilan seorang pendidik dalam mengelola kelas.

Pendidik bahasa Arab yang kompeten adalah ia yang mempunyai kecerdasan yang tinggi, sehingga mampu menguasai materi pembelajaran secara baik, dapat mengelola kelas secara tepat, dapat menggunakan metode dan media yang sesuai dengan kondisi peserta didik dan ruang blajar, dapat menumbuhkan motivasi belajar pada peserta didik dan dapat mengukur kemajuan proses pembelajaran yang berlangsung (Munir, 2017: 80).

Dilihat dari kedudukannya, posisi pendidik sebagai orang yang mendidik haruslah mempunyai keterampilan lebih selain penguasaan terhadap materi. Melainkan juga terampil dalam memahami kemampuan yang dimiliki individu peserta didik. Keterampilan tersebut nantinya dapat menjadikan ke-kreatifan pendidik dalam menggunakan strategi dan media pembelajaran yang disesuaikan dengan keadaan peserta didik. Mengingat kembali bahwa bahasa Arab merupakan pembelajaran bahasa Asing dan kiurang diminati keberadaannya di Indonesia. Oleh sebab itu, pendidik dituntut sebisa mungkin berupaya memunculkan semangat dan minat peserta didik terhadap bahasa Arab, supaya memudahkan diterimanya materi bahasa Arab.

Selain dituntut memiliki keterampilan memahami kemampuan peserta didik, pendidik bahasa Arab juga dituntut dapat mengelola kelas secara tepat. 
Pengelolaan kelas yang tepat adalah pengelolaan yang didasarkan realitas kelas yang sesungguhnya. Peserta didik merupakan realitas utama yang harus menjadi dasar pengelolaan kelas. Seorang pendidik yang baik, ia harus mampu mengidentifikasi kondisi peserta didik yang sesungguhnya. Kondisi yang dimaksud adalah modalitas yang dimiliki, setting sosial, kemampuan dasar yang dimiliki, dan tingkat kecerdasan mereka. Sudah seyogyanya seorang pendidik mengetahui jumlah anak yang memiliki modalitas visual, berapa jumlah anak yang memiliki modalitas auditorial dan berapa banyak anak yang memiliki modalitas kinestetik. Aspek lain yang harus diperhatikan adalah kemampuan dasar bahasa Arab yang dimiliki oleh peserta didik, berapa jumlah anak yang mempunyai kemampuan dasar tinggi, berapa banyak anak yang memiliki kelemahan pada aspek istima', aspek qiro'ah, aspek kitabah, dan aspek kalam. Dengan memahami realitas seperti itu, maka pendidik akan lebih mudah bagaimana ia mengelola kelas secara tepat dan hasil pembelajaran dapat optimal (Munir, 2017: 80-81).

Adapun beberapa strategi yang dapat dilakukan pendidik dalam menciptakan lingkungan belajar yang kondusif adalah sebagai berikut (Harjali, 2016: 13-17).
a. Menata kenyamanan dan keindahan perabot kelas.
b. Penataan tempat duduk
c. Penggunaan media dalam kegiatan pembelajaran
d. Motivasi pendidik
e. Interaksi antar peserta didik

Selain penerapan strategi yang dilakukan dalam pengelolaan kelas, seorang pendidik juga harus mengetahui hal-hal apa saja yang disenangi oleh peserta didik sehingga memudahkan pendidik dalam mengatur jalannya kegiatan pembelajaran. Beberapa teknik yang dapat dilakukan oleh pendidik dalam memahami hal-hal yang disenangi oleh peserta didik antara lain: 
a. Suka membantu kesulitan peserta didik dalam mengerjakan tugas, menerangkan pelajaran dengan jelas serta mendalam dan menerapkan contohcontoh sebagai aplikasi dari penerapan materi yang dipelajari.

b. Riang, gembira, dan mempunyai perasaan humor.

c. Bersikap akrab dan membaur dengan peserta didik.

d. Menunjukan perhatian pada peserta didik dan memahami mereka.

e. Berusaha agar pekerjaan sekolah dapat menarik dan membangkitkan keinginan belajar.

f. Tegas, sanggup menguasai kelas, membangkitkan rasa hormat pada peserta didik.

g. Tidak pilih kasih.

h. Tidak suka mengomel, mencela, mengejek, menyindir.

i. Betul-betul mengajarkan sesuatu kepada murid yang berharga bagi mereka.

j. Mempunyai pribadi yang menyenangkan

(S. Nasution, 200: 15)

Dari beberapa uraian diatas, pendidik dapat berupaya seoptimal mungkin dalam menciptakan kelas yang sesuai dengan harapan peserta didik, tentunya tetap dengan berdasarkan kaidah-kaidah yang berlaku dalam pengelolaan kelas bahasa Arab. Hal ini dapat diupayakan dengan cara penerapan strategi dalam pembelajaran maupun dengan cara memahami apa saja yang disenangi oleh peserta didik ketika pembelajaran berlangsung. Sehingga dengan demikian, lingkungan pembelajaran yang diciptakan dapat mengahadirkan rasa aman, nyaman, dan menyenangkan dapat dirasakan oleh peserta didik.

\section{Peran Peserta Didik dalam Menciptakan Kelas yang Menggairahkan}

Dalam pengelolaan kelas terdapat dua unsur yang keduanya saling bekerjasama, yaitu pendidik dan peserta didik. Kesuksesan dalam pengelolaan kelas tidak akan tercapai jika peserta didik tidak terlibat di dalamnya. Peserta didik adalah manusia yang dapat berpikir, mempunyai kehendak, berambisi 
terhadap cita dan rasa yang menguntungkan, dengan segala kelebihan dan kekurangannya. Bila kondisi demikian tidak dikelola secara tepat, makan akan terjadi benturan-benturan di antara mereka. Oleh karena itu, harus ada solusi yang tepat agar perbedaan ambisi, cara berpikir, dan karakter mereka tidak merusak suasana kelas. Langkah-langkah yang diperlukan untuk mengantisipasi hal tersebut dan supaya suasana kelas tetap menggairahkan adalah dengan menanamkan niat yang kuat, menyadari manfaat setiap tindakan, menjalin rasa saling pengertian, rasa saling memiliki dan keyakinan akan kemampuan masingmasing dalam mencapai kesuksesan belajar (Munir, 2017: 84).

Niat mempunyai kekuatan yang luar biasa dalam menciptakan tindakan dan kualitasnya. Niat merupakan kekuatan yang terpendam di dalam diri, dan menjadi 'motor' penggerak setiap tindakan. Bila semua peserta didik berhasil menanamkan niat untuk belajar, maka belajar akan menjadi aspek utama di dalam proses pembelajaran berlangsung. Bila belajar merupakan aspek utama bagi peserta didik, maka aspek-aspek yang dapat mengganggu proses pembelajaran dapat dikesampingkan.

Aspek lain yang juga penting untuk dijaga, adalah kesadaran terhadap akibat dari setiap tindakan. Untuk menjaga konsistensi prinsip ini dapat dipermudah dengan cara membuat akronim yang mudah diingat, seperti dengan kata "AMBAK", yakni Apa Manfaatnya Bagiku (DePorter, 2000: 45). Bila "AMBAK" menjadi sumber kesadaran setiap tindakan, maka semua tindakan peserta didik akan mengarah pada hal-hal yang positif dan bekualitas. Untuk mendukung kesadaran eksistensi masing-masing individu di tengah-tengah masyarakat belajar lainnya perlu dipupuk rasa saling pengertian dan jalinan emosional diantara mereka. Jalinan hubungan ini dapat menciptakan lingkungan sosial kelas kondusif untuk saling mengambil manfaat setiap kelebihan dan memperbaiki kesalahan masing-masing individu. Bila aspek-aspek tersebut dapat dikembangkan secara baik, maka suasana pembelajaran di dalam kelas akan mendatangkan keriangan, kegairahan, dan ketakjuban. 


\section{Kaidah Membangun Kelas yang Menggairahkan}

Kaidah dalam konteks ini adalah landasan komunitas belajar dalam membangun sistem interaksi selama mengikuti proses pembelajaran di kelas. Kaidah-kaidah tersebut meliputi kesepakatan, kebijakan, prosedur, dan peraturan yang dijadikan sebagai pedoman bagi setiap anggota komunitas belajar di kelas (Munir, 2017: 85).

Kesepakatan, akan menjaga ketertiban dan menuntun setiap tindakan yang dilakukan baik oleh pendidik maupun peserta didik. Dengan adanya kesepakatan maka proses pembelajaran akan berjalan dengan lancar. Kebijakan kelas, merupakan pengejawantahan tujuan komunitas belajar kelas. Kebijakan juga menjelaskan urutan tindakan untuk situasi tertentu, misalnya ketika peserta diidk tidak dapat hadir, maka ia harus meminta tugas yang tidak bisa diikutinya kepada pendidik yang bersangkutan. Prosedur, memberi tahu peserta didik apa yang diharakan, tindakan apa yang harus dilakukan. Dengan adanya prosedur ini dapat melatih kedisiplinan. Prosedur yang telah mentradisi akan menjadi rutinitas dan menjadi bagian dari kehidupan kehidupan komunitas beljaar seharihari. Peraturan, peraturan menimbulkan konsekuensi yang jelas terhadap peserta didik yang melanggar peraturan yang telah disepakati.

\section{Pengelolaan Kelas}

Pengelolaan kelas adalah upaya yang dilakukan pendidik atau pendidik dalam menciptakan dan memelihara kondisi dan keadaan belajar secara optimal untuk menggiring peserta didik kearah pendisiplinan diri untuk belajar di kelas (Pandeirot, 2014). Dalam pengertian lain, dijelaskan bahwa pengelolaan kelas adalah pengadministrasian, pengaturan, atau penataan suatu kegiatan (Djamarah' 2002: 175).

Sedangkan pengertian pengelolaan kelas dalam pembelajaran bahasa Arab adalah upaya pendidik bahasa Arab dalam menciptakan kondisi atau lingkungan belajar yang menarik, positif, dan aktif. Peserta diidik senantiasa 
aktif mengikuti aktivitas pembelajaran, tidak merasa bosan atau takut pada materi bahasa Arab.

Tujuan adanya pengelolaan kelas menurut Ekawati (2018:103) adalah sebagai berikut:

a. Mewujudkan situasi dan kondisi kelas, baik sebagai lingkungan belajar maupun sebagai kelompok belajar yang memungkinkan pembelajar untuk mengembangkan kemampuan semaksimal mungkin.

b. Menghilangkan berbagai hambatan yang dapat menghalangi terwujudnya interaksi pembelajaran.

c. Menyediakan dan mengatur fasilitas serta perabot belajar yang mendukung dan memungkinkan pebelajar belajar sesuai dengan lingkungan sosial, emosional, dan intelektual pembelajar dalam kelas.

d. Membina dan membimbing sesuai dengan latar belakang sosial, ekonomi, budaya serta sifat-sifat individunya

Sebagaimana salah satu peranan pendidik adalah sebagai pengelola kelas, maka hendaknya pendidik harus dapat mengelola kelas dengan baik dan mengelola hasil belajar. Pendidik bahasa arab hendaknya bisa menghilangkan anggapan dari peserta didik bahwa pelajaran bahasa Arab susah dan menjenuhkan. Anggapan itu bisa diubah jika pendidik bahasa Arab bisa menciptakan suasana yang nyaman dan menyenangkan selama kegiatan pembelajaran berlangsung, memberikan selingan dengan sedikit humor sehingga peserta didik menjadi tertarik dan senang. Dengan ketertarikan mereka dan perasaan senang yang timbul dari masing-masing individu peserta didik terhadap aktivitas pembelajaran bahasa Arab itu sendiri. Maka akhirnya peserta didik pun akan mengatakan bahwa bahasa Arab itu mudah, bahasa Arab itu menarik, dan belajar bahasa Arab itu menyenangkan (Ekawati, 2018: 102).

Pengelolaan kelas pada dasarnya merupakan penataan kelas yang ditata sedemikian rupa agar dapat mendukung efektivitas dan efisiensi pencapaian tujuan pembelajaran. Pengelolaan kelas yang tepat akan mampu meningkatkan kesadaran, efektivitas daya dengar, pasrtisipasi, dan umpan balik peserta didik 
mengenai segala sesuatu yang disampaikan oleh pendidik (Munir, 2017: 78). Kondisi lingkungan belajar yang nyaman menjadi perhatian penting dalam pengelolaan kelas, karena lingkungan belajar mempunyai hubungan timbal balik dengan perkembangan peserta didik. Lingkungan yang baik berpengaruh terhadap pembentukan watak peserta didik ke arah yang lebih baik. Sebaliknya, lingkungan yang kurang teratur kurang tertata, kurang bersih, dan kurang aman akan menyebabkan menurunnya motivasi belajar peserta didik.

Terkait dengan kegiatan pengelolaan kelas meliputi kegiatan secara garis besar terdiri dari: (Kompri, 2002: 142)

a. Pengaturan orang (peserta didik). Peserta didik adalah orang yang meakukan aktivitas dan kegiatan di kelas yang ditempatkan sebagai objek dan arena perkembangan ilmu pengetahuan dan kesadaran manusia, maka peserta didik bergerak kemudian menduduki fungsi sebagai subjek.

b. Pengaturan fasilitas. Aktivitas dalam kelas baik pendidik maupun peserta didik dalam kelas kelangsungannya akan banyak dipengaruhi kondisi dan situasi fisik lingkungan kelas.

Pengelolaan kelas merupakan salah satu keterampilan yang harus dimiliki bagi seorang pendidik. Pengelolaan kelas merupakan upaya yang dilakukan dalam mempertahankan kondisi kelas yang nyaman dan proses pembelajaran dapat terlaksanakan secara optimal. Beberapa aspek penting yang harus diperhatikan mengenai pengelolaan kelas, yaitu: suasana, landasan, lingkungan, dan rancangan (Munir, 2017: 78). Karena kelas sebagai tempat utama dalam proses pembelajaran, biasanya terdapat kerjasama antara pendidik dengan peserta didik dalam mengatur dan menciptakan kelas yang nyaman agar materi yang disampaikan oleh pendidik dapat diserap dengan mudah oleh peserta didik. Kerjasama yang terbentuk dalam mengelola kelas tersebut dapat berupa dekorasi kelas yang dipadukan dengan kreatifitas peserta didik, model pembelajaran yang disesuaikan dengan materi, mengatur posisi meja dan kursi, pencahayaan ruang, musik dan lain sebagainya. 
Dengan kata lain, kelas harus disulap sedemikian rupa sehingga menimbulkan suasana yang nyaman sebagai tempat belajar dan dapat memunculkan semangat belajar peserta didik.

\section{a. Komponen-komponen Keterampilan Mengelola Kelas}

Komponen-komponen keterampilan pengelolaan kelas pada umumnya dibagi kepada dua pembagian, yaitu:

1) Keterampilan yang berhubungan dengan penciptaan dan pemeliharaan kondisi belajar yang optimal (bersifat preventif)

Keterampilan ini berhubungan dengan kompetensi pendidik dalam mengambil inisiatif dan mengendalikan pelajaran serta aktivitas-aktivitas yang berkaitan dengan keterampilan antara lain:

a) Sikap Tanggap

Komponen ini ditunjukkan oleh tingkah laku pendidik, bahwa pendidik hadir bersama peserta didik. Pendidik tahu kegiatan peserta didik, apakah memperhatikan atau tidak, tahu apa yang peserta didik kerjakan. Seakan mata pendidik ada di belakang kepala, sehingga pendidik bisa menegurnya walaupun sedang menulis di depan kelas.

b) Membagi Perhatian

Pengelolaan kelas yang efektif dapat terjadi bila pendidik mampu membagi perhatiannya kepada beberapa kegiatan yang berlangsung dalam waktu yang sama.

\section{2) Keterampilan yang berhubungan dengan pengembangan kondisi yang optimal.}

Keterampilan ini berkaitan dengan tanggapan pendidik terhadap peserta didik yang bermasalah. Hal ini dimaksudkan agar pendidik dapat mengadakan tindakan remendial untuk mengembalikan kondisi yang optimal. Apabila terdapat peserta didik yang menimbulkan gangguan yang berulang-ulang, pendidik sudah menggunakan tindakan dan tanggapan yang sesuai, pendidik bisa meminta bantuan kepada kepala 
sekolah, konselor sekolah, dan orangtua peserta didik untuk mengatasinya (Asmadawati, 2014: 9).

\section{b. Prinsip-prinsip Pengelolaan Kelas}

Dalam sebuah perencanaan tentunya tidak lepas dari sebuah prinsip yang mana adanya prinsip tersebut menjadi tameng dalam penerapan rencana yang yang telah disusun dalam mengelola kelas. beberapa prinsip yang digunakan dalam pengelolaan kelas, yaitu: (Johar, 2016: 162)

1) Hangat dan Antusias

Hangat dan antusias diperlukan dalam proses pembelajaran. Pendidik yang hangat dan akrab dengan peserta didik, selalu menunjukkan antusias pada tugasnya dan aktivitasnya akan berhasil dalam mengimplementasikan pengelolaan kelas.

2) Tantangan

Penggunaan kata-kata, tindakan cara kerja atau bahan-bahan yang menantang akan meningkatkan gairah peserta didik untuk belajar sehingga mengurangi kemungkinan munculnya tingkah laku yang menyimpang. Tantangan juga dapat menarik perhatian peserta didik dan dapat mengendalikan gairah belajar mereka.

3) Bervariasi

Penggunaan alat bantu atau media, gaya mengajar pendidik, pola interaksi antara pendidik dengan peserta didik yang bervariasi akan mengurangi munculnya gangguan dan meningkatkan perhatian peserta didik. Kevariasian merupakan kunci untuk tercapainya pengelolaan kelas yang efektif dan menghindari kejenuhan.

4) Keluwesan

Keluwesan tingkah laku pendidik untuk mengubah strategi mengajar, dapat mencegah kemungkinan munculnya gangguan peserta didik serta menciptakan iklim pembelajaran yang efektif.

5) Penekanan Pada Hal-hal yang Positif 
Dalam mengajar dan mendidik, pendidik harus menekankan pada hal-hal yang positif dan menghindari pemusatan perhatian peserta didik pada hal-hal yang negatif. Penekanan pada hal positif yang dimaksudkan yaitu penekanan terhadap tingkah laku anak yang positif daripada mengomentari tingkah laku peserta didik yang negatif.

\section{c. Pendekatan dalam Pegelolaan Kelas}

Pengelolaan kelas (classroom management) berdasarkan pendekatannya diklasifikasikan ke dalam tiga pengertian, yaitu berdasarkan pendekatan otoriter (authority approach), pendekatan permisif (permissive approach) dan pendekatan modifikasi tingkah laku. Adapun macam-macam pendekatan pengelolaan kelas antara lain (Majid, 2005: 87).

1) Pendekatan kekuasaan

Pendekatan kekuasaan yaitu pendidik menciptakan dan mempertahankan situasi disiplin dalam kelas. Kedisiplinan adalah kekuatan yang menuntut murid untuk mentaatinya. Di dalam kelas ada kekuasaan dan norma yang mengikat untuk ditaati anggota kelas.

2) Pendekatan Pengajaran

Pendekatan pengajaran, pendekatan ini didasarkan atas suatu anggapan bahwa dalam perencanaan dan pelaksanaannya akan mencegah munculnya masalah tingkah laku murid dan memecahkan masalah itu bila tidak bisa dicegah.

3) Pendekatan Kerja Kelompok

Pendekatan kerja kelompok, dalam pendekatan ini pendidik menciptakan kondisi-kondisi yang memungkinkan kelompok yang produktif, selain itu pendidik juga harus dapat menjaga kondisi itu agar tetap baik.

4) Pendekatan Elektis atau Pluralistic

Ketiga pendekatan tersebut oleh pendidik digabungkan digunakan untuk mengelola kelas. Sehingga tercipta pendekatan elektis atau pluralistic. Pendekatan elektis yaitu pendidik kelas memilih berbagai pendekatan tersebut berdasarkan situasi yang dihadapi, dalam suatu situasi mungkin 
dipergunakan salah satu dan dalam situasi yang lain mungkin mengkombinasikan ketiga pendekatan tersebut.

Adapun dalam Zulhanan dijelaskan bahwa pendekatan-pendekatan dalam pembelajaran bahasa Arab adalah sebagai berikut:

1) Pendekatan Struktural

Pendekatan ini difungsikan iuntuk mengukur tingkat penguasaaan terhadap satu jenis keterampilan berbahasa atau unsur berbahasa.

2) Pendekatan Fungsional

Pendekatan ini berharap kepada pendidik dan peserta didik memilih dan menganalisis tujuan yang akan realisasikan sehingga selaras dengan pilihan materi yang akan diaktualisasikan.

3) Pendekatan Komunikatif

Pendekatan ini merupakan bagian dari strategi pembelajaran yang berkaitan dengan tujuan tertentu yaitu melatih peserta didik melalui presentasi dan inovasi bahasa, serta bukan hanya sekedar bagusnya gramatikal yang disajikan (Ekawati, 2018: 105).

Beberapa macam-macam pendekatan diatas dapat menjadi pilihan bagi pendidik bahasa Arab dalam melaksanakan kegiatan mengajar bahasa Arab di kelasnya dengan tetap memperhatikan pengelolaan kelas yang tepat demi tercapainya tujuan pembelajaran bahasa Arab.

\section{d. Rancangan dalam Pengelolaan Kelas}

Dalam kegiatan pengelolaan, tentu tidak lepas dengan adanya suatu rancangan menganai proses pengelolaan tersebut. Begitu juga halnya dengan pengelolaan kelas yang membutuhkan suatu rancangan untuk merencanakan kegiatan yang sistematis supaya tujuan pengelolaan apat tercapai. Faktor-faktor yang mempengaruhi penyusunan rancangan pengelolaan kelas adalah sebagai berikut: (Ekawati, 2018: 106)

1) Pemahaman terhadap arti, tujuan, dan hakikat peneglolaan kelas, akan memberikan arah kepada apa, mengapa dan bagaimana harus berbuat dalam pengelolaan kelas. 
2) Pemahaman terhadap hakikat peserta didik yang dihadapinya. Yaitu setiap saat seorang peserta didik akan memperlihatkan sikap dan tingkah laku tertentu dalam lingkungannya.

3) Pemahaman terhadap bentuk penyimpangan serta latar belakang tindakan peyimpangan yang dilakukan oleh peserta didik, melalui identifikasi masalah penyimpangan yang dihadapinya.

4) Pemahaman terhadap pendekatan-pendekatan yang dapat digunakan dalam pengelolaan kelas. Pemahaman ini akan menambah kemampuan dalam menyesuaikan pendekatan tertentu dengan masalah penyimpangan yang dilakukan oleh peserta didik.

5) Pemilikan pengetahuan dan keterampilan dalam membuat rancangan pengelolaan kelas.

Beberapa langkah diatas bisa menjadi acuan bagi pendidik daalam aktivitas mengajarnya di kelas. Hendaknya pendidik memahami tujuan dari pengelolaan kelas, memahami sifat masing-masing peserta didiknya, mengidentikikasi masalah-masalah baik secara idividu atau kelompok, menyusun rancangan pengelolaan kelas dengan baik dan melaksanakan rancangan pembelajaran yang telah disusun.

\section{e. Indikator Keberhasilan Pengelolaan Kelas dalam Pembelajaran Bahasa Arab}

Beberapa indikator yang bisa dilihat dalam pengelolaan kelas diantaranya; (Ekawati, 2018: 106)

1) Pendidik bahasa Arab memahami perbedaan antara pengelolaan kelas dan mendisiplinkan kelas.

2) Seorang pendidik bahasa Arab jika telah selesai melaksanakan tugas mengajar dan kembali pulang ke rumah tidak dalam keadaan yang sangat lelah.

3) Pendidik bahasa Arab mengerti perbedaan antara prosedur kelas dan rutinitas kelas. 
4) Pendidik bahasa Arab melakukan pengelolaan kelas dengan mengorganisir prosedur-prosedur, sebab prosedur mengajarkan peserta didik akan pentingnya tanggung jawa dalam mengajar.

5) Pendidik bahasa Arab tidak mendisiplinkan peserta didik dengan ancaman-ancaman, dan konsekuensi (penghilangan peserta didik dan lain-lain).

6) Pendidik bahasa Arab mengerti bahwa perilaku peserta didik di kelas disebabkan oleh suatu faktor, sedangkan disiplin bisa dipelajari.

Dari beberapa indikator tersebut, diharapkan pendidik bahasa Arab sebaiknya memperhatikan beberapa indikator yang bisa dijadikan acuan dalam pengelolaan kelasnya. Memahami setiap individu peserta didiknya dan berusaha menghindari anacaman-ancaman ketika peserta didik belum memiliki ketertarikan untuk mengikuti pembelajaran bahasa Arab dengan tertib, dan melaksanakan proses pembelajaran dengan perasaan senang.

\section{Simpulan}

Pengelolaan dalam pembelajaran bahasa Arab merupakan keterampilan pendidik bahasa Arab dalam menciptakan, mengorganisasi, mengatur, dan mengelola kelas sehingga tercipta suasana kelas yang kondusif, nyaman, dan menyenangkan serta meminimalisir hambatan-hambatan yang muncul dalam proses pembelajaran sehingga tujuan pembelajaran bahasa Arab yang meliputi mepat ketetampilan berbahasa yaitu keterampilan istima', keterampilan qiro'ah, keterampilan kalam, dan keterampilan kitabah.

Dalam kegiatan pembelajaran, pengelolaan kelas sangat dibutuhkan karena merupakan faktor penentu keberhasilan suksesnya pembelajaran. Dalam kegiatan mengelola kelas, dibutuhkan keterampilan, strategi, prinsip, pendekatan, dan rancangan yang disusun secara sistematis sehingga dalam mengelola kelas pendidik dapat lebih mudah membawa dan mengarahkan peserta didik kepada seperti apa nantinya kegiatan pembelajaran berlangsung. 
Selain peran pendidik, peran pendidik pun berpengaruh dalam proses mengelola kelas karena pendidik dan peserta didik merupakan dua unsur wajib yang berperan dalam kegiatan mengelola kelas. Antara pendidik dan peserta didik diharapkan dapat bekerja sama dalam keberhasilan mengelola kelas yang kondusif dan dapat mempermudah peserta didik dalam menerima materi pembelajaran bahasa Arab yang diajarkan.

Mengelola kelas merupakan bagian keterampilan yang harus dimiliki oleh pendidik. Adapun keterampilan-keterampilan yang harus dimiliki pendidik dalam mengelola kelas yaitu keterampilan yang berhubungan dengan penciptaan dan pemeliharaan kondisi belajar yang optimal (bersifat preventif) dan keterampilan yang berhubungan dengan pengembangan kondisi yang optimal. Beberapa prinsip yang harus dipegang oleh pendidik dalam mengelola kelas antara lain: prinsip hangat, prinsip antusias, prinsip tantangan, prinsip bervariasi, prinsip keluwesan, dan prinsip penekanan pada hal-hal yang positif. Sedangkan pendekatan-pendekatan yang dapat dilakukan pendidik dalam mengelola kelas berupa: pendekatan struktural, pendekatan fungsional, pendekatan komunikatif, dan pendekatan Quantum Teaching and Leearning. Pendidik bahasa Arab hendaknya juga memahami rancangan dan indikator -indikator pencapaian keberhasilan tujuan pembelajaran dengan ditentukan bagaimana pengelolaan kelas bisa berjalan dengan baik dan efektif. 


\section{DAFTAR PUSTAKA}

Asmadawati, "KETERAMPILAN MENGELOLA KELAS", Logaritma II, No. 02 (2014).

DePorter, Bobbi dan Mike Hernacki. Quantum Learning, Membiasakan Belajar Nyaman dan Menyenangkan. Bandung: Kaifa, 2000.

Djamarah, Syaiful Bahri dan Aswan Zain, Strategi Pembelajaran. Jakarta: Rineka Cipta, 2002.

Ekawati, Dian. “An-Nabighoh, Strategi Pengelolaan Kelas Pembelajaran Bahasa Arab". 20, No. 01, (2018)

Harjali, "PENDIDIKAN DAN PEMBELAJARAN, Strategi Pendidik dalam Membangun Lingkungan Belajar yang Kondusif: Studi Fenomenologi pada kelas-kelas Sekolah Menengah Pertama di Ponorogo” 23, No. 1, (2016): 13-17

Johar, Rahmah dan Latifah Hanum. STRATEGI PEMBELAJARAN. Yogyakarta: DEEPUBLISH, 2016.

Kompri, Manajemen Sekolah, Teori dan Praktik. Bandung: Alfabeta, 2002.

Kompri, Motivasi Pembelajaran Perspektif Pendidik dan Peserta didik, Bandung: Remaja Rosdakarya, 2016.

Majid, Abdul. Perencanaan Pembelajaran. Bandung: Rosda Karya, 2005.

Munir, Perencanaan Sistem Pengajaran Bahasa Arab Teori dan Praktik. Jakarta: KENCANA, 2017.

Nasution, S. DIDAKTIK ASAS-ASAS MENGAJAR. Jakarta: Remaja Rosdakarya, 2000.

Pandeirot, Nyoman Surna-olga D. Psikologi Pendidikan 1. Jakarta: Erlangga, 2014.

Sardiman, Interaksi dan Motivasi Pembelajaran. Jakarta: Raja Grafindo Persada, 2005.

Supardi, Kinerja Pendidik. Jakarta: Rajawali Pers, 2004.

Usman, Moch. Uzer. MENJADI PENDIDIK PROFESIONAL. Bandung: PT. REMAJA ROSDAKARYA, 2009.

Wiyani, Novan Ardy. Manajemen Kleas: Teori dan Aplikasi untuk Menciptakan Kelas yang Kondusif. Yogyakarta: Ar Ruzz Media, 2013. 